\title{
Desenvolvimento de Um Protótipo de Barra de Cereal Contendo Proteína Texturizada de Soja $\mathrm{Na}$ Formulação
}

Fernanda Moreira Holland Pedroza (I), Renato Soares Gusmão (I), Paola Alves Sigarini (I), Leticia Maria Magalhães Arruda (I), Elis

Caroline Celestina Dos Santos (I), Cleise Oliveira Sigarini (I)

(I) UFMT - UNIVERSIDADE FEDERAL DE MATO GROSSO (Av. Fernando Corrêa da Costa, no 2367 - Bairro Boa Esperança. Cuiabá - MT - 7806)

\section{Resumo}

INTRODUÇÃO: As barras de cereais são feitas a partir da compactação de frutas desidratadas e de cereais como a aveia, o trigo, a soja, o milho e o arroz. A popularidade no mercado deve-se a sua praticidade, aos seus valores nutricionais e ao seu sabor. O grão da soja vem sendo considerado, por ser uma importante fonte proteica rica em substâncias como isoflavonas, fibras e esteróis que possuem propriedades funcionais. Essas substâncias previnem de doenças degenerativas como câncer, osteoporose, diabetes, doenças cardiovasculares e menopausa. Este trabalho objetivou elaborar uma barra de cereais contendo soja, com características nutricionais que atendam a necessidade de praticantes de atividades físicas e publico em geral. METODOLOGIA: Os ingredientes foram adquiridos no comércio local da cidade de Cuiabá - MT e elaboração da barra de cereal foi realizada no laboratório de Técnica Dietética da UFMT. Foram utilizadas duas formulações e apresentadas á um grupo de provadores não treinados com o objetivo de verificar a aceitabilidade da melhor formulação. Para averiguar alterações organolépticas do produto, amostras da formulação escolhida foram armazenas em duplicata, sendo uma em temperatura ambiente e outra em estufa à $40^{\circ} \mathrm{C}$ durante sete dias. Em seguida, foram submetidas à pesquisa de Staphylococcus aureus, Bacillus cereus, e Coliformes. RESULTADOS E DISCUSSÃO: Durante o 
desenvolvimento da segunda formulação observou-se maior rigidez apresentada pela mistura, tornando tal fato um obstáculo para a homogeneização e corte da massa, sendo desta forma, escolhida a primeira formulação como padrão. A degustação resultou que o sabor das frutas secas destacou-se de forma positiva e tornou o sabor da soja imperceptível. No período de estocagem, à $40^{\circ} \mathrm{C}$ em estufa para uma amostra e outra a temperatura ambiente, por sete dias, as amostras mantiveram estáveis com perda leve de suas características sensoriais, mais resistentes e opacos. CONCLUSÃO: As pesquisas de S. aureus, B. cereus e coliformes, estavam dentro do padrão da legislação nacional vigente. A barra de cereal contendo proteína texturizada de soja mostrou-se viável do ponto de vista sensorial e microbiológico.

Palavras-Chave: cereal, soja, qualidade microbiológica Agência de Fomento: 